\title{
STRUCTURAL CONTROL ON DEVELOPMENT OF KARST LANDSCAPE IN THE SALENTO PENINSULA (APULIA, SE ITALY)
}

\author{
STRUKTURNI VPLIV RAZVOJA KRAŠKEGA POVRŠJA NA \\ POLOTOKU SALENTO (APULIJA, JV ITALIJA)
}

\author{
Mari Pepe ${ }^{1} \&$ Mario Parise ${ }^{2}$
}

\begin{abstract}
UDC 551.435.8(450.75)

Mari Pepe \& Mario Parise: Structural control on development of karst landscape in the Salento Peninsula (Apulia, SE Italy)

Apulia region (SE Italy) is particularly prone to karst processes, due to the extensive presence of carbonate rocks. Karst marks the whole region, and represents the main landscape features, with a variety of landforms ranging from large-size dolines, to poljes, and fluvial-karstic valleys; given the configuration of Apulia, a great role in the presence of widespread karst features is also played by coastal landforms. The Salento peninsula, in southern Apulia, is characterized by very low relief and cropping out of different types of carbonate rocks, ranging in age from Cretaceous to Quaternary. Recognition of karst features in this setting, and the likely implications for geohazards, is quite difficult, because of the subtleness of the features, and the facility for man to cancel or modify them. Nevertheless, the presence of dolines is definitely a typical aspect of the area, which also implies some consequences in terms of risk to the built-up environment. This work focuses on the area of Barbarano del Capo, where two cover-collapse dolines are well known in the geological literature as Vora Grande and Vora Piccola. Despite the fact that morphometrical and stratigraphical features have already been investigated, few informations are available about the hydro-geomorphological and structural settings of the area. This article presents the results of morphological and structural analyses, aimed to understand the role of tectonics in the development of karst features, and their evolution.

Keywords: sinkholes, karst, tectonics, morphometry, karst landforms, Salento peninsula, Apulia.
\end{abstract}

Izvleček

UDK 551.435.8(450.75)

Mari Pepe \& Mario Parise: Strukturni vpliv razvoja kraškega površja na polotoku Salento (Apulija, JV Italija)

Za pokrajino Apulijo (JV Italija) so značilni kraški procesi, zaradi velike razširjenosti karbonatnih kamnin. Kras označuje celotno pokrajino in predstavlja glavne površinske oblike, od velikih vrtač, do polj in fluvialnih kraških dolin. Glede na položaj Apulije imajo pomembno vlogo $\mathrm{v}$ prisotnosti razširjenih kraških oblik tudi obalne površinske oblike. Polotok Salento $\mathrm{v}$ južni Apuliji kaže značilnosti nizkega reliefa $\mathrm{z}$ izdanki različnih karbonatnih kamnin krednih do kvartarnih starosti. Določanje kraških oblik ter povezava $\mathrm{z}$ naravnimi nesrečami je težka zaradi razširjenosti oblik in zmožnosti človeka, da preoblikuje površje. Kljub temu je prisotnost vrtač zelo značilna za to pokrajino. Hkrati pa to lahko povzroča nekatere neugodne posledice pri gradnjah na tem terenu. Ta študija je usmerjena na območje Barbarano del Capo, kjer se nahajata dve pokriti udorni vrtači, v geološki literaturi dobro znani kot Vora Grande in Vora Piccola. Kljub temu, da so bile morfometrične in stratigrafske oblike že raziskane, pa je malo dostopnega o hidro-geomorfoloških in strukturnih podatkih. Članek predstavlja rezultate morfoloških in strukturnih analiz, da bi razumeli vlogo tektonike v razvoju kraških oblik.

Ključne besede: vrtače, kras, tektonika, morfometrija, kraške površinske oblike, polotok Salento, Apulija.

\footnotetext{
${ }^{1}$ Basin Authority of Apulia, Valenzano, Italy, e-mail: mari.pepe81@gmail.com

${ }^{2}$ CNR-IRPI, Bari, Italy, e-mail:m.parise@ba.cnr.itpi.it

Received/Prejeto: 23.09.2013
} 


\section{INTRODUCTION}

Karst processes are the main geomorphic agents in Apulia region (SE Italy), due to the extensive presence of carbonate rocks, ranging from the Jurassic to the Quaternary ages. Karst landforms are widespread all over the region, and often designated with different terms. As a matter of fact, due to historical reasons the local language developed distinct and variable linguistic roots in different parts of the region. Thus, even the terms used to indicate the natural landscape greatly change throughout Apulia. This is, for instance, the case of dolines, one of the most common features in the Apulian landscape: a high variety of dolines has been documented, with different genesis, morphology and size, governed by the local characteristics of carbonate rock masses and hydrology. Dolines are designated with very different terms, such as pulo, gurgo, grave, àviso, and vora, depending on the local dialects (see Parise et al. 2003).

The Salento peninsula, hosting the southernmost carbonate block of the region, is entirely modeled by karst processes, and particularly susceptible to dolines, due to favourable stratigraphic conditions: among the other types, many examples of cover-collapse dolines (sensu Waltham et al. 2005) can be numbered, promoted by the presence of Tertiary and Quaternary clastic carbonates over the Cretaceous limestone bedrock (e.g. Delle Rose et al. 2004, 2007; Parise 2008a; Festa et al. 2012).

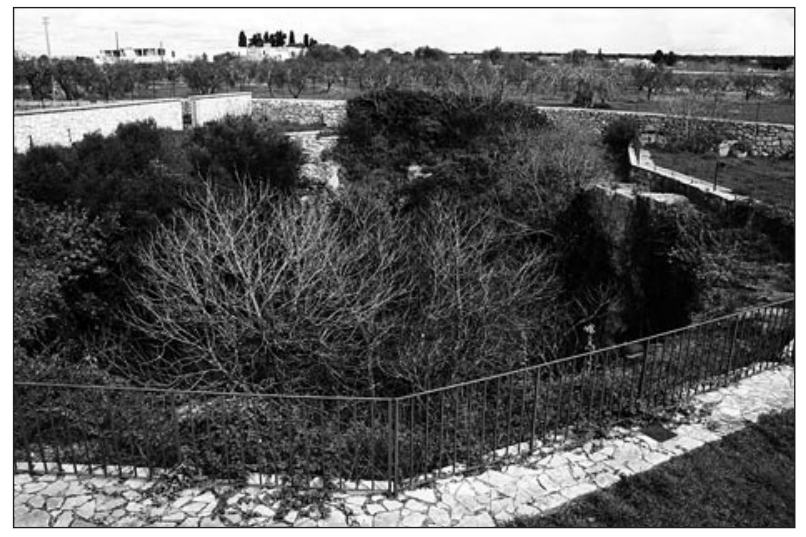

Fig.1: Overall view of Vora Grande (Photo: M. Parise).

Seawater along the Salento coastlines enhances hyperkarst processes, that are at the origin of the wide presence of coastal dolines (Delle Rose \& Parise 2002, 2005; Delle Rose et al. 2004; Parise 2008a; Bruno et al. 2008a, b; Del Prete et al. 2010; Margiotta et al. 2012). In particular, the interplay between coastal doline activity and sea wave erosion produces on the Ionian side of Salento peculiar shoreline morphologies, locally designated as spunnulate (e.g. Bruno et al. 2008a and references therein; Basso et al. 2013). In addition to dolines produced by natural karst processes, many cases of anthropogenic sinkholes have been registered in Salento, ascribed to intense underground quarrying (e.g. Delle Rose et al. 2007; Parise 2008a, 2010a; De Pascalis et al. 2010; Lollino \& Parise 2010; Parise \& Lollino 2011; Lollino et al. 2013).

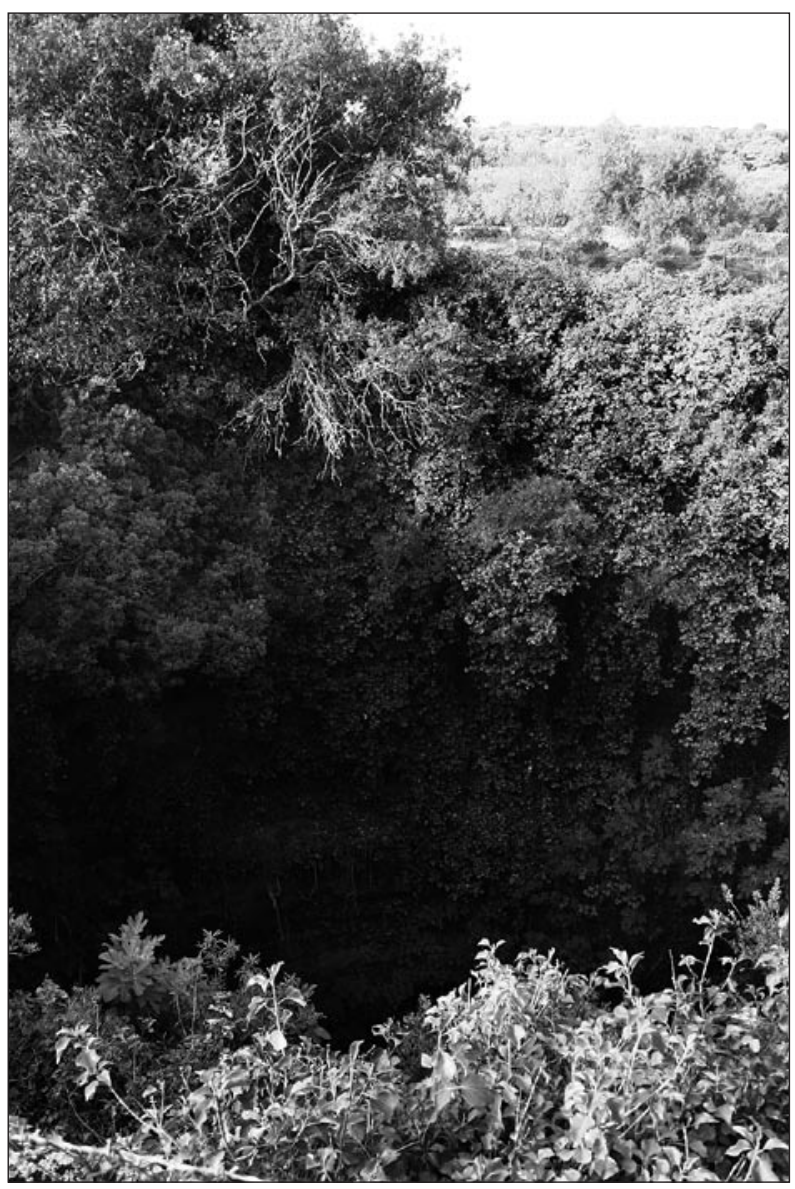

Fig. 2: Vora Piccola (Photo: M. Parise).

Together with dolines, other depression-like landscapes are extremely important in terms of land management in the karst of Apulia: these can cover limited areas, often hosting temporary lakes or marshlands (Lopez et al. 2009; Parise 2009), or affect larger territories as poljes (Parise 2006). Since these depressions represent the low-altitude lands, they are often flooded in the aftermath of heavy rainstorms, a situation which results in continuous heavy economic losses in Salento, and the rest of Apulia as well (Parise 2003; Andriani \& Walsh 
2009; Cotecchia \& Scuro 2010). The effects of the floods are often exacerbated by land mismanagement actions, typically carried out without having a proper knowledge of the karst landforms and their hydrological functioning (Calò \& Parise 2006; Parise \& Gunn 2007; De Waele et al. 2011). Closure and clogging of swallow holes, and extensive covering of karst with asphalt roads and the expansion of urbanized areas obstruct the natural drainage of runoff during and after heavy rainstorms, enhancing the consequent losses to society.

Starting from the above considerations, this work examines the main landforms of the karst landscape in a sample area of Salento, namely Barbarano del Capo, where two cover-collapse dolines are well known in the geological literature as Vora Grande (Fig. 1) and Vora Piccola (Fig. 2), for their respective sizes. Both dolines, few hundreds of meters apart, are included in the Regional Register of Caves, managed by the Apulian Speleological Federation (Giuliani 2000) and were carefully described for the first time by a local scholar, Cosimo De Giorgi, at the end of the XIX century (De Giorgi 1896). Further morphological descriptions have been provided by Beccarisi et al. (2003), Delle Rose et al. (2004) and Parise (2008a). All these authors agree that both dolines formed through collapse of the cavern vaults, enhanced by local litho- stratigraphical changes in the Plio-Pleis- tocene calcarenites. At present, they still show instability conditions, as testified by the recent fall at the eastern margin of Vora Grande (February 2011).

The two Vore are also interesting examples of the interaction between man and development of dolines: remains of quarry activity at the margin of one of the doline might represent evidence of a likely (even though so far not proved) anthropogenic trigger. The abundance of quarries in this site is due to the common employment of calcarenites for buildings in the past. Ancient human activities in this site are also testified by carriage tracks of Roman age (Sammarco \& Parise 2008).

The abundance and variety of karst landforms, involving various kinds of carbonate rocks, with different textures and cementation degree, makes this area suitable for geological evaluations on development of the karst landscape. In particular, this work estimates the possible connection between the shape of morphokarst elements and the spatial distribution of mechanical discontinuities in the rock masses, as already tried in several karst areas worldwide, including the Classical Karst (i.e., Šebela 1998; Cucchi et al. 2001; Šebela et al. 2005, and references therein). Quantitative methods have been employed for both the morphometry of karst landforms and the structural analysis.

\section{METHODS}

Given the main aim of the work (that is, to look for, and discuss, any likely relationships between the main features of karst landforms and the geological structures), to perform the morphometric analysis of dolines in the study area, a detailed hydro-geomorphological map has been realized, based upon field surveys and interpretation of multi-temporal aerial photographs, covering the time span from 1955 to 2001. Recognized elements have been drawn up in a digital format using as base the topographic map at 1:5.000 scale provided by Apulia Region, and Geographic Information System (GIS) tools have been employed to manage the spatial data. In particular, a hierarchical distinction among the recognized morphokarst elements has been outlined, based on visibility, extension and depth. The term doline refers in our work to topographically depressed areas of generally limited extent, showing a marked altitude drop. These latter are often enclosed in wider, flatter depressions, with boundaries more difficult to be outlined, and that show a less appreciable difference in altitude with respect to surrounding areas. Thus, dolines and depressions will be the two categories of karst features mostly dealt with in the following analyses and descriptions. In addition, the main scarps bordering the Serre ridges, and the few ephemeral streams arising from these slopes, have also been outlined.

Cartographical data have been then employed for the morphometric analysis, carried out separately on the two categories of dolines and depressions. The following parameters, considered as the most representative for a morphometric description of the considered karst landforms (e.g. Williams 1971; Drake \& Ford 1972; Mills \& Starnes 1983), have been adopted: i) Total number; ii) Minimum and maximum area; iii) Density (total number / total area); iv) Total area; v) Percentage of involved areas; vi) Ratio between major axis (a) and minor axis (b) (elongation ratio, e.g. Bruno et al. 2008a).

Finally, the structural analysis has been undertaken. Dip-directions of faults and joints have been measured and statistically analyzed at the available outcrops of the carbonate rock masses (the Cretaceous limestone 
bedrock and the Pleistocene calcarenites). Spatial distribution of measurement stations provides a quite uniform outline of structural data across the study area. A total number of 15 measurement stations have been selected, 8 of which are located along the Serre ridges (Serre di Montesardo to the north-east and Serre Falitte to the south-west), whilst the remaining 7 along the interven- ing structural lowlands. At each station, a minimum number of 40 measurements has been assumed as the threshold of statistical significance. Results have been then analyzed and plotted on rose diagrams and cumulative curves, in order to detect the likely connections between structural data and morphometric parameters.

\section{GEOLOGICAL AND GEOMORPHOLOGICAL SETTING}

The Apulia region represents the outcropping sector of the south-Apennines foreland, connected to the westward subduction of the Adria Plate underneath the Apennine
Chain (Mostardini \& Merlini 1986; Casero et al. 1988; Doglioni 1991), since Late Oligocene to Early Pleistocene (Boccaletti et al. 1990). Regionally the Apulian

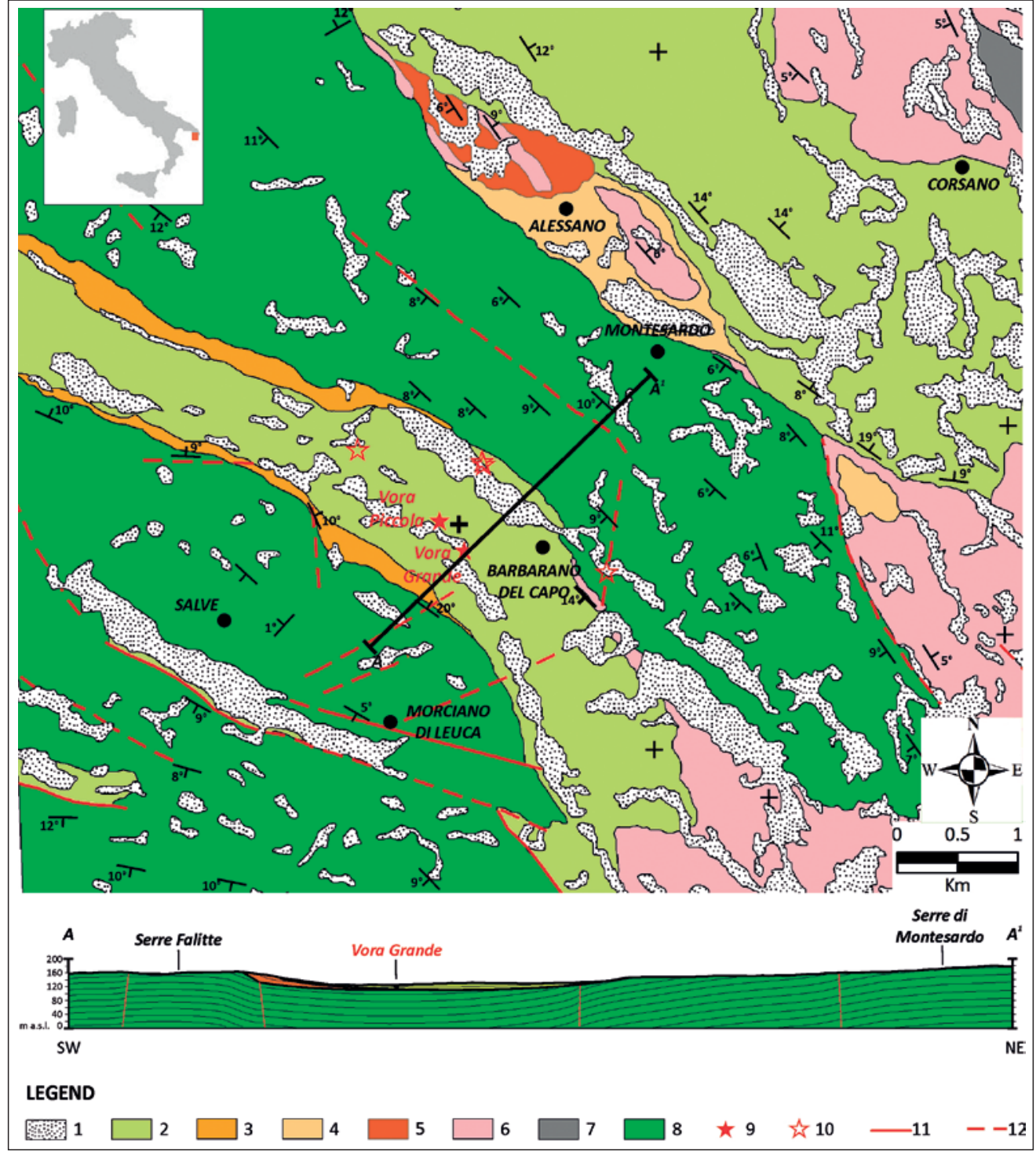

Fig. 3: Sketch map and cross-section of the study area (modified after Ricchetti and Ciaranfi, 2009 - sheet 536 Ugento of the New Geological Map of Italy, 1:50.000 scale). Legend:

1. Eluvial-colluvial deposits (Middle Pleistocene Holocene); 2. Miggiano Synthem (Middle Pleistocene);

3. Gravina Calcarenites Fm. (Lower Pleistocene); 4. Uggiano La Chiesa Fm. (Middle-Upper Pliocene); 5. Trubi (Lower Pliocene); 6. Andrano Calcarenites Fm. (Upper Miocene); 7. Castro Limestone Fm. (Upper Oligocene); 8. Altamura Limestone Fm. (Upper Cretaceous); 9. Active sinkhole; 10. Filled sinkhole; 11. Fault; 12. Uncertain fault. 


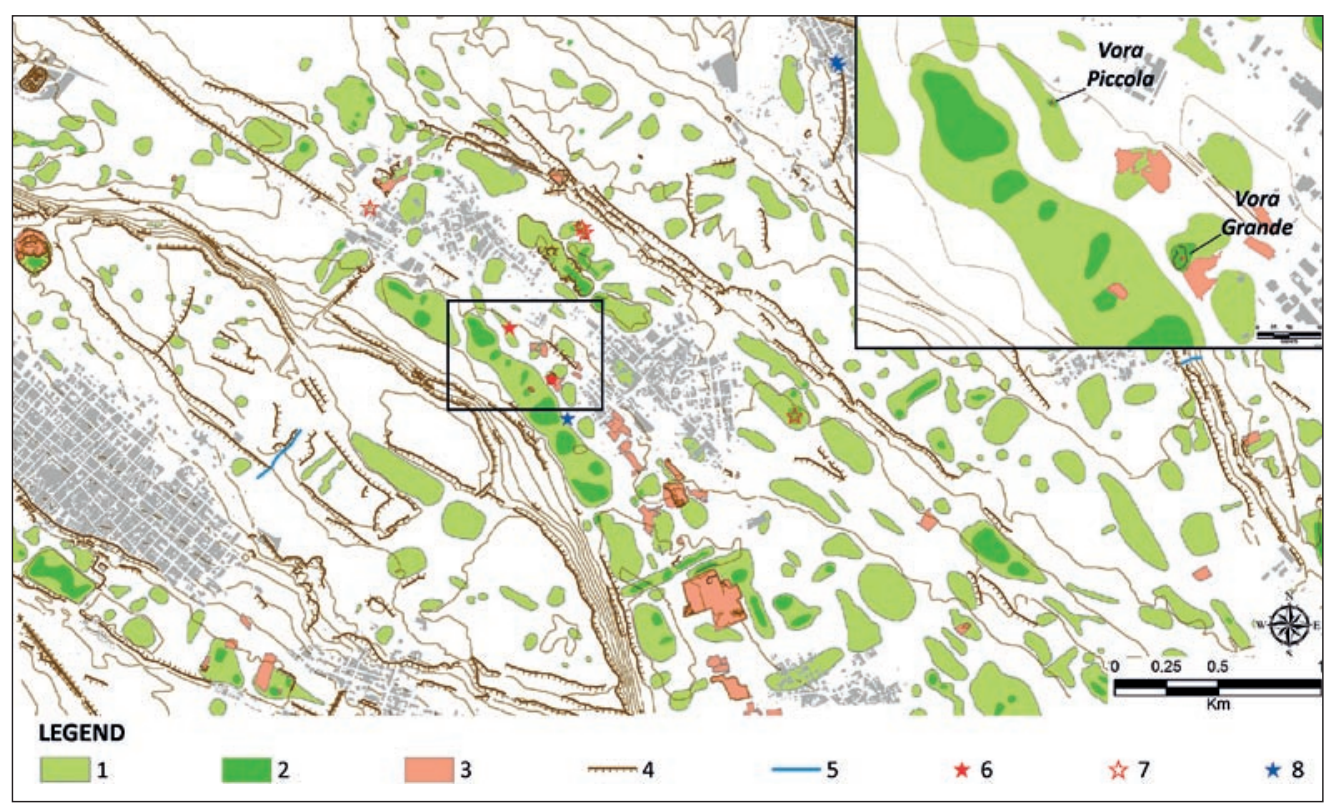

Fig. 4: Hydro-geomorphological map of the study area, with detail of the two Vore (inset in the upper right corner).

Legend: 1. Depression; 2. Doline; 3. Quarry; 4. Scarp; 5. Stream; 6. Active sinkhole; 7. Filled sinkhole; 8. Artificial cave.

Foreland corresponds to a wide WNW-ESE trending antiform (Ricchetti 1980; Royden et al. 1987), due to buckling of the subducting slab. The exposed sector of the antiform is segmented by large deformation zones in three main blocks, represented from north to south by the Gargano, the Murge and the Salento highlands (Ricchetti et al. 1988; Funiciello et al. 1991; Gambini \& Tozzi 1996). This latter represents the less uplifted block and performs the lowest topographic relief.

The strong development of karst-landscape in most of Apulia is definitely ascribable to the preponderance of carbonate rocks, originated in different palaeo-geographical settings. From bottom to top, the overall carbonate sedimentary succession is composed of Jurassic-Cretaceous limestones and dolostones of a passive margin (the so-called Murge Limestones Group), from 3 to $5 \mathrm{~km}$ thick, unconformably overlain by Palaeogene to Neogene calcarenites and calcirudites of foreland to foredeep settings, unevenly preserved only in the Gargano highland and the Salento Peninsula, finally capped by Quaternary terraced marine calcarenites.

Accordingly, many carbonate units are exposed in the study area, ranging from Cretaceous to Quaternary ages, with lateral and vertical changes in both facies and mechanical properties (Fig. 3). Following the new Geological Map of Italy (1:50.000 scale), the oldest unit at the outcrop is represented by Upper Cretaceous limestones of inner-shelf (Altamura Limestone Fm.), unconformably overlain by Upper Miocene to Lower Pleistocene calcarenites and calcirudites of intertidal to neritic environments (Andrano Calcarenites, Trubi, Uggiano-La Chiesa and Gravina Calcarenites Fms.), finally capped by Middle Pleistocene terraced marine calcar- enites of intertidal setting (Miggiano Synthem). The Altamura Limestone Fm., representing the Cretaceous bedrock, is exposed along narrow, NW-SE-trending ridges (the so-called Serre Salentine), whilst the overlying deposits are preserved in the intervening structural lowlands with the lowest stratigraphic units only exhumed along the footslopes of the Serre margins. The two Vore are hosted within the Miggiano Synthem, made up of medium to coarse macro-fossiliferous calcarenites and calcirudites, with diffuse bioturbation, referable to an intertidal environment (Ricchetti \& Ciaranfi 2009 - sheet 536 "Ugento" of the Geological Map of Italy, at the 1:50.000 scale).

The hydro-geomorphological map (Fig. 4) shows that the morphological pattern of the study area mainly follows the regional structures. Karst landscape is dominated by dolines and depressions, while fluviokarst valleys appear to be limited to the fault scarps bounding the Serre Salentine. The major axes of both dolines and depressions present NW-SE and NE-SW main trends. Along the structural lowlands intervening between the Serre ridges, the depressions are typically wider and more markedly elongated in a NW-SE direction. Vora Grande and Vora Piccola are located on the same NW-SE-elongated plain, bounded by the ridges of Falitte Serre to the south-west, and of Montesardo Serre to the north-east. From these two lateral ridges to the intervening plain, elevation drops about 20-30 m: this altitude gap is sufficient to produce a variety of landforms, as in other inland sectors of Salento (Palmentola 1987; Parise 2008b). 


\section{COVER-COLLAPSE DOLINES IN BARBARANO DEL CAPO: VORA GRANDE AND VORA PICCOLA}

Vora Grande and Vora Piccola are located at the eastern periphery of Barbarano del Capo, few hundreds of meters from the Sanctuary of Madonna del Belvedere in Leuca Piccola, which hosts an interesting underground crypt dug into the local calcarenites, a remarkable example of the ability to realize man-made underground cavities in the area (Sammarco \& Parise 2008).

Vora Grande (PU 114 in the Register of Natural Caves of Apulia), actually fenced-in all along, is situated southeast of Vora Piccola (PU 115), in turn located few tens of meters far from the country road to the Sanctuary. The two Vore respectively reach $35 \mathrm{~m}$ and $25 \mathrm{~m}$ of depth. In plan view, Vora Grande shows an elliptical shape, with a NS-oriented, $30 \mathrm{~m}$-long major axis. Elongation changes in depth, following a NW-SE orientation (Beccarisi et al. 2003). Vora Piccola, instead, shows a less-pronounced elliptical shape in plan view, with a 15 m-long major axis, oriented in NW-SE direction. These two sites still show instability conditions, as an effect of the geomechanical degradation of rock masses and the vertical to over-hanging walls: a big volume of rock recently (February 2011) fell from the southeastern margin of Vora Grande, due to intense rainfalls and likely favored by discharge of runoff water that is channeled into the doline by means of pipes (Pepe and Parise 2011; Fig. 5).

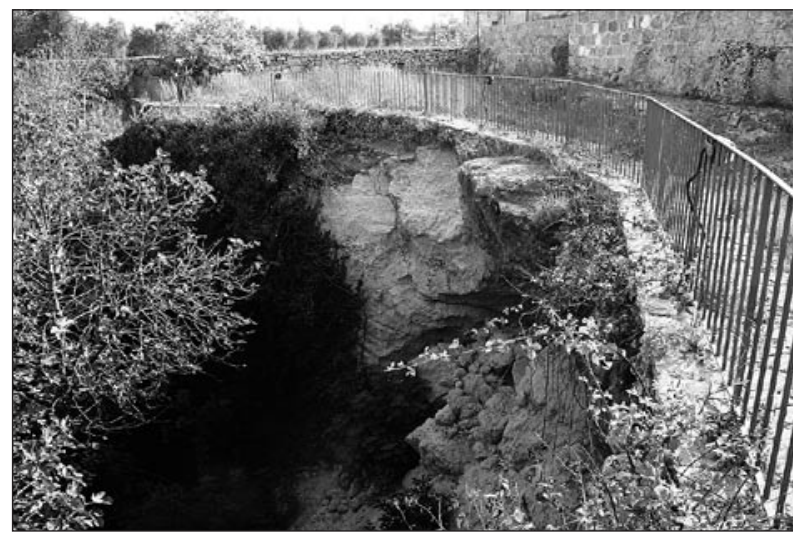

Fig. 5: Recent fall at the eastern margin of Vora Grande in February 2011 (Photo: M. Parise).

Both Vore affect the Middle Pleistocene deposits of the Miggiano Synthem. The detailed litho-stratigraphic description of the sedimentary succession exposed along their walls is provided by Bossio et al. (1987, 1998). From bottom to top, the sedimentary succession consists of: yellowish calcarenites and calcirudites, arranged in dm-thick beds, exposed below $20 \mathrm{~m}$ of depth; yellowish carbonate-rich sands, about 15-15.5 m thick, with more lithified layers in the uppermost 4-5 meters; well-lithified calcarenites, about 4.5-5 m thick. Selective erosion highlights diagenetic changes in the upper part of the succession. Furthermore, thin karst conduits and intrastratal caves are cut by the walls of the Vore. Therefore, combined karst and mechanical erosion has promoted the genesis of rock ledges overlooking inside the caves. These ledges are locally accessible by artificial ways, dug into the calcarenites. Wide detrital cones lay at the bottom of the Vore, clogging any possible exploration of the underground cave systems.

Assuming a basal karst level about 10-20 m below the current bottom of the Vore, Beccarisi et al. (2003) have worked out an evolutionary model of the two dolines, starting with the genesis of a proto-cave, following with its widening under chemical and mechanical processes, and with the upward migration of the vaults by collapse of the cavern roofs. These processes were probably enhanced by the involvement of more erodible sandy layers. This rapid evolution easily brought to reach the calcarenite layers on top, without any need for further chemical processes (e.g. condensation) aiding carbonate solution, and not properly testified by morphological evidences (Dunne 1990; Parise 2008a). The final collapse of the remaining cap, resulting in doline opening, was probably promoted by the presence of mechanical discontinuities in the calcarenite layers above the underground voids.

The exact definition of the absolute time of opening of the doline is still a challenge. A clue is noticeable along the margins of Vora Piccola, where traces of quarries are cut by the walls of the sinkhole. This element provides information about relative timing, suggesting that quarries were prior to doline opening (Delle Rose et al. 2004; Parise 2008a). It is not excluded that quarry activity may have triggered the collapse, but this should require stronger evidences.

Apart from Vora Grande and Vora Piccola, the analysis of multi-year air-photos has revealed the presence in the study area of at least four more collapse dolines, filled after the "70s and now part of the inhabited area. A strong drop in floor is still recognizable at these places (Fig. 6). Despite the number of samples it is insufficient for any statistical statement, anyway some general features of these collapse dolines can be outlined. In plan view, they mainly show sub-circular shapes, with diameters in the order of few tens of meters. When slight elongation occurs, the major axes follow NNW-SSE trends. As regards position, all collapse dolines are lo- 
cated in the plain intervening between the Serre Falitte and the Serre di Montesardo, nearby the lowermost topographical sectors of wider depressions. However, not all collapse dolines involve Middle Pleistocene calcarenites

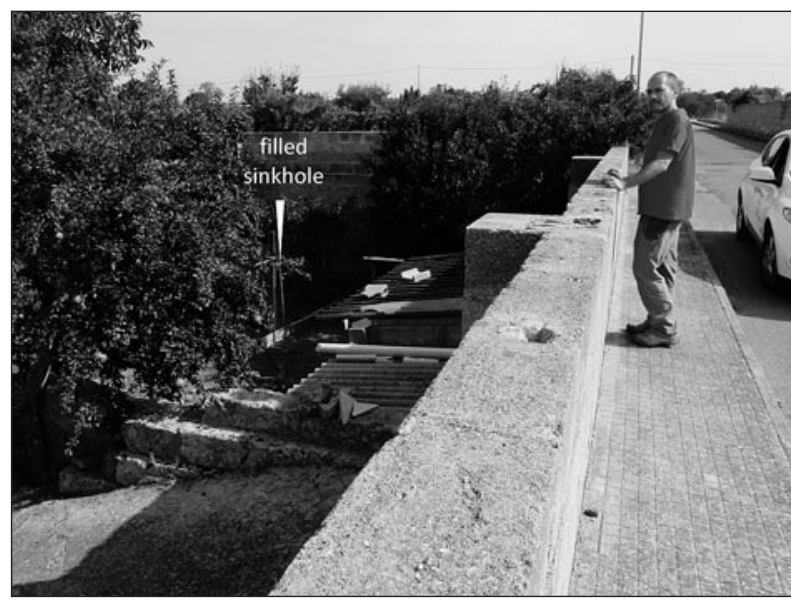

Fig. 6: Evidence of an ancient sinkhole, today partly filled and included in the anthropogenic setting (Photo: M. Pepe). of the Miggiano Synthem: one of them, in fact, is hosted within the Cretaceous limestones of the Altamura Limestone Fm (Fig. 3), with no sedimentary cover involved, unless eroded. In this case, the vicinity of the Serre di Montesardo fault scarp (Fig. 4) may be liable for a belt of mechanical weakness, where karst processes have been enhanced.

Apart from the aforementioned collapse dolines, a number of solution dolines have also been detected, scattered along the main morpho-structural plains. At first glance, these landforms seem to be randomly shaped. A more careful insight reveals that smaller dolines mainly perform circular shapes; larger dolines tend to elliptical, or anyway elongated, shapes. As observed by Bruno et al. (2008a) in other karst areas of Apulia region, this feature can be ascribed to coalescence of neighbouring dolines, where elongation is controlled by alignment of incipient dolines. However, elongation of dolines not always coincides with that of the depressions where they are included (Fig. 4).

\section{RESULTS}

\section{MORPHOMETRIC ANALYSIS}

The morphometric analysis of the karst landforms performs different values of all parameters, whether considering dolines or depressions (Tab. 1). The total number of depressions is 274 , corresponding to a density of 11.87 in the total area of study $\left(20 \mathrm{~km}^{2}\right)$. As concerns dolines, the density value drops to 8.10 , with 86 features identified. In terms of total extent, the considered landforms diverge one order of magnitude: the total surface coverage of depressions is $2.93 \mathrm{~km}^{2}$, against the $0.25 \mathrm{~km}^{2}$ of dolines. Accordingly, in terms of percentage, depressions represent $14.63 \%$ of the total area, and dolines only $1.26 \%$. Depressions and dolines show also different values of the mean major axis / minor axis ratio $(\mathrm{a} / \mathrm{b})$, indicating a higher elongation in the former. The parameter elongation is defined as the ratio of the equivalent circular diameter to the major axis length (Schumm 1956). It indicates that the most elongated among depressions concentrate in the range $80-100^{\circ}$ of the azimuth values, while dolines are elongated in the range of $0-20^{\circ}$ (Fig. 7).

Taking into account the azimuth values of the major axes of both the categories of landforms, the outcomes reveal that dolines and depressions show similar orientations, both following Apenninic trends. In particular, the maximum peak for dolines $(25 \%)$ is at $100-120^{\circ}$, whilst for depressions $(30 \%)$ it is at $120-140^{\circ}$ (Fig. 8). Being

Tab. 1: General morphometric features of dolines and depressions in the study area.

\begin{tabular}{l|c|c}
\hline Area of survey & \multicolumn{2}{|c}{$20 \mathrm{~km}^{2}$} \\
\hline Number of elements & DEPRESSIONS & DOLINES \\
\hline Minimum area & 274 & $0.00019109 \mathrm{~km}^{2}$ \\
\hline Maximum area & $0.00027769 \mathrm{~km}^{2}$ & $0.02274375 \mathrm{~km}^{2}$ \\
\hline Density & $0.16924151 \mathrm{~km}^{2}$ & 8.10 Dolines $/ \mathrm{km}^{2}$ \\
\hline Total area & 11.87 Depressions $/ \mathrm{km}^{2}$ & $0.25 \mathrm{~km}^{2}$ \\
\hline Percentage & $2.93 \mathrm{~km}^{2}$ & $1.26 \%$ \\
\hline Major axis (a) / minor axis (b) ratio & $14.63 \%$ & 1.88 \\
\hline
\end{tabular}



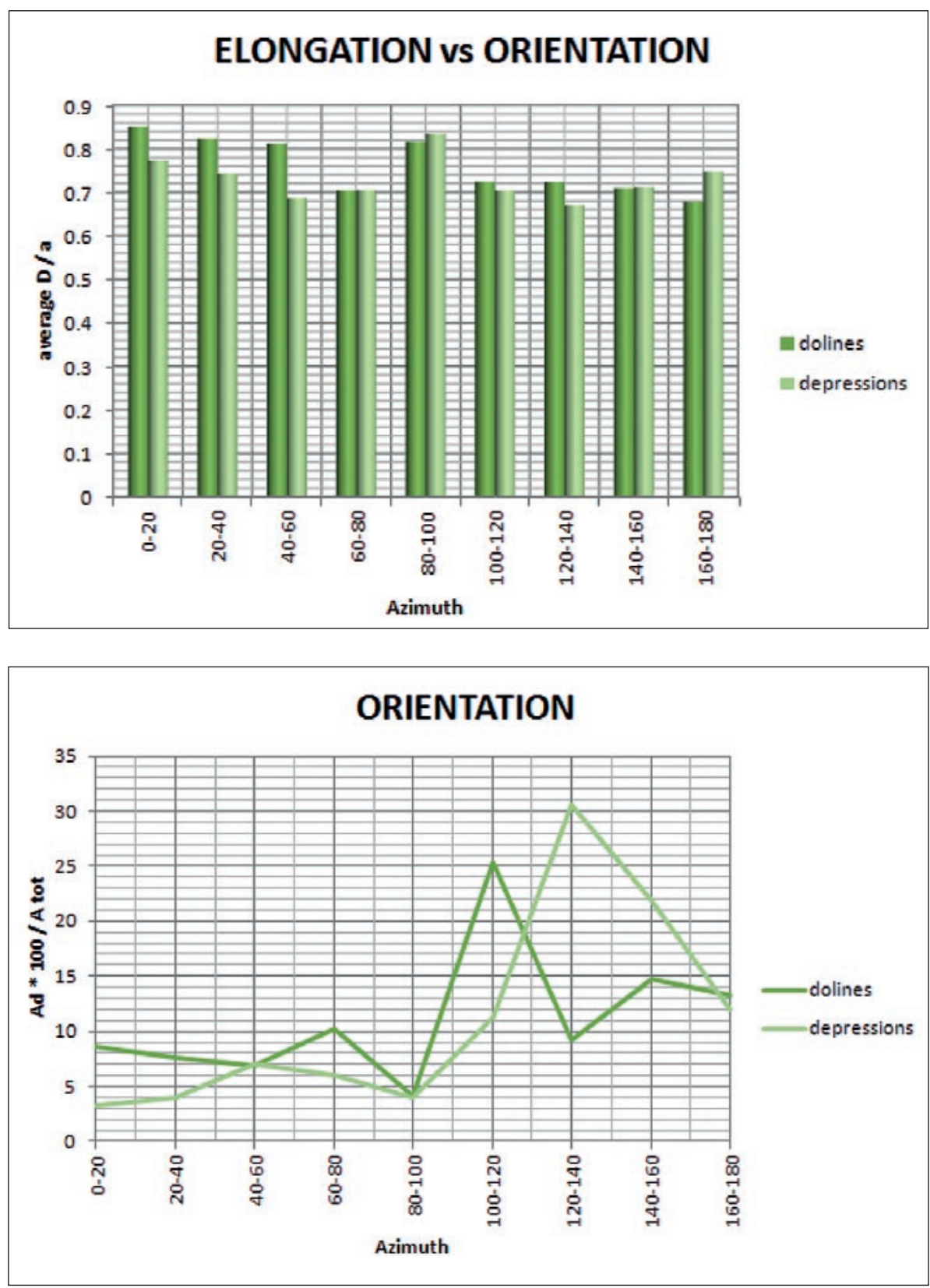

Fig. 7: Histogram showing elongation values for dolines and depressions, depending on the azimuth values $(D=$ diameter of equivalent circle).

Fig. 8: Cumulative curves of major axes orientations, respectively for dolines and for depressions $\left(A_{d}=\right.$ area of individual doline or depression; Atot $=$ total area of dolines or of depressions).

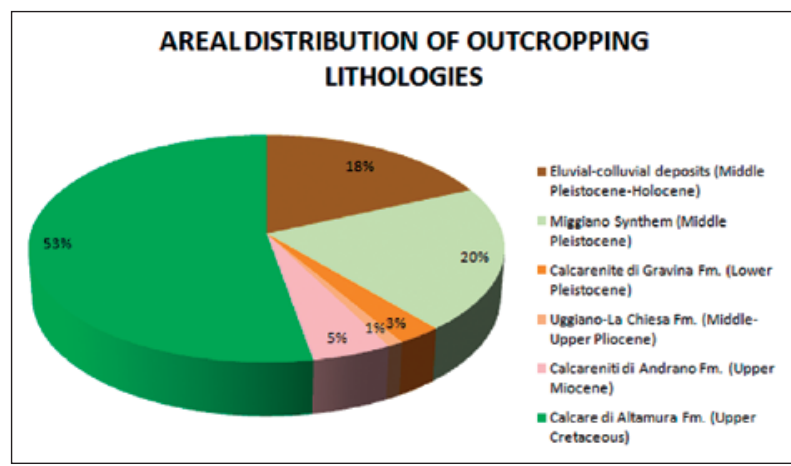

Fig. 9: Areal distribution of outcropping lithologies. the study area geologically characterized by a high variety of carbonate rocks at the outcrop (Fig. 9), a further analysis of the morphometric data seems necessary, as a function of lithologies. In this analysis, the Holocene eluvial-colluvial deposits have not been taken into account. Computation of the areal percentages of dolines and depressions, depending on the lithologies involved (Fig. 10), has highlighted that the most karstified unit is the youngest one, the Miggiano Synthem, with 23\% of its area involved in depressions. The Andrano Calcarenites follow very close (22\% areal coverage for depressions) whilst significantly low is the area affected by depression for Uggiano la Chiesa Fm. Minor differences can be 


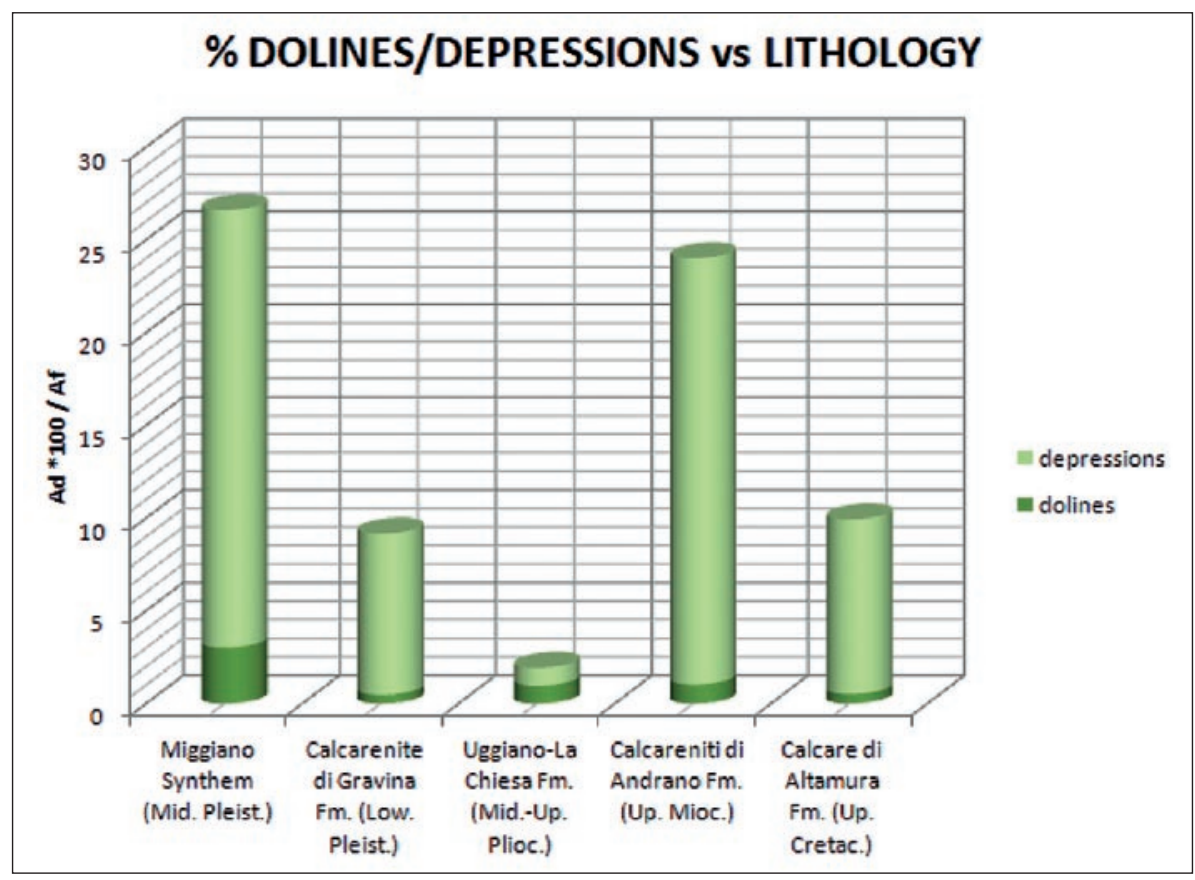

Fig. 10: Areal percentages of dolines and depressions, as a function of lithologies $\left(A_{d}=\right.$ area of individual doline or depression; Af = area of individual lithology).

Tab. 2: Summary of prevailing major axes orientations of karst landforms according to the different lithologies.

\begin{tabular}{l|c|c}
\hline \multirow{2}{*}{$\begin{array}{l}\text { LITHOLOGICAL } \\
\text { UNITS }\end{array}$} & \multicolumn{2}{|c}{ AZIMUTH VALUES ( ${ }^{\circ}$ ) } \\
\cline { 2 - 3 } & Dolines & Depressions \\
\hline Miggiano Synthem & $100-120$ & $120-160$ \\
Gravina Calcarenites Fm. & $120-140$ & $140-160$ \\
Uggiano-La Chiesa Fm. & - & $60-80$ \\
Andrano Calcarenites Fm. & $160-180$ & $120-140$ \\
Altamura Limestone Fm. & $140-160$ & $120-140$ \\
\hline
\end{tabular}

observed among the various lithologies when analyzing dolines: in this case, all the rock types show similar values, with the maximum again for the Miggiano Synthem (3\% areal coverage).

Finally, cumulative curves of the azimuth values of the major axes highlight a net preponderance of Apenninic trends, in both dolines and depressions sets for all the lithologies, with the only exception of the UggianoLa Chiesa Fm., that shows a trend about ENE-WSW (Fig. 11). Nevertheless, the data seem more concentrated for the samples of depressions, whilst the doline azimuth

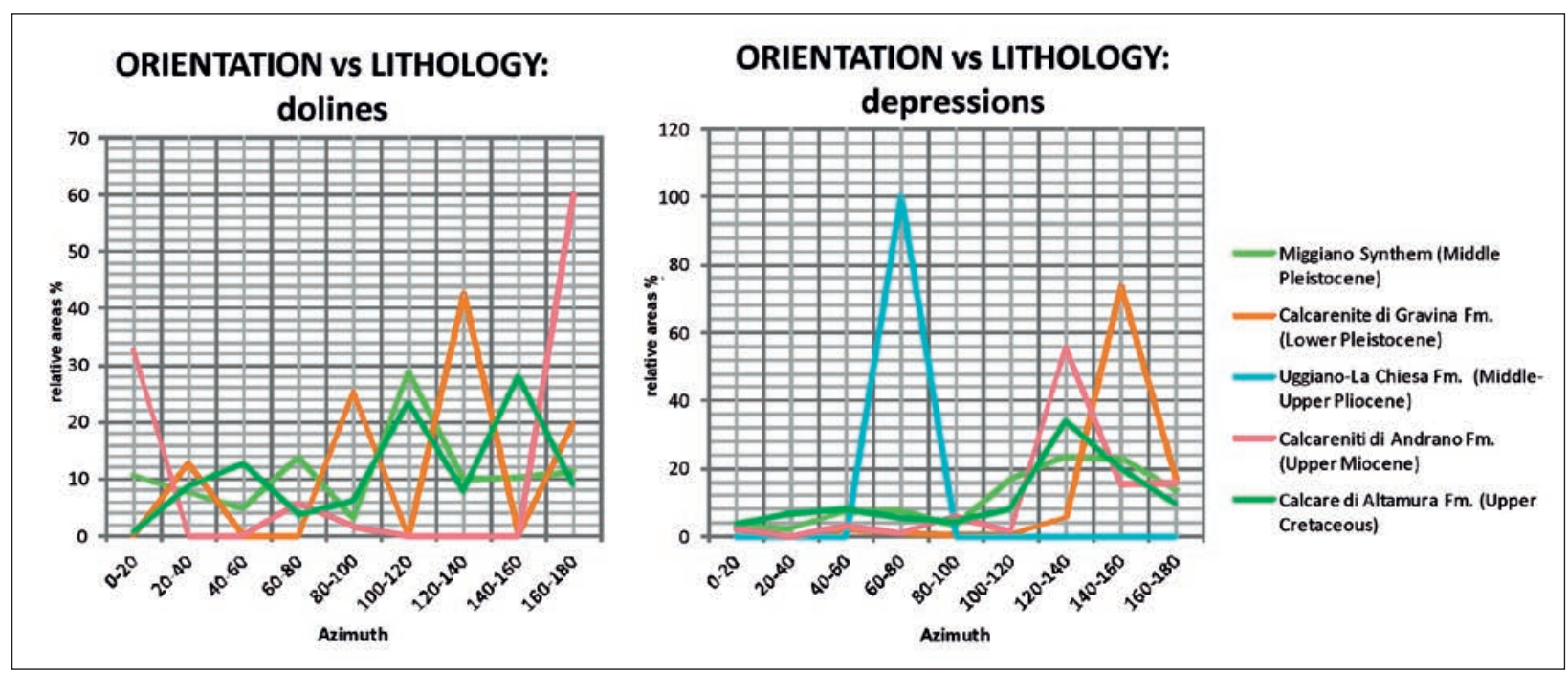

Fig. 11: Azimuth values of major axes of dolines and depressions, as a function of lithology. Relative areas refer to the total area of dolines in individual lithological unit. 


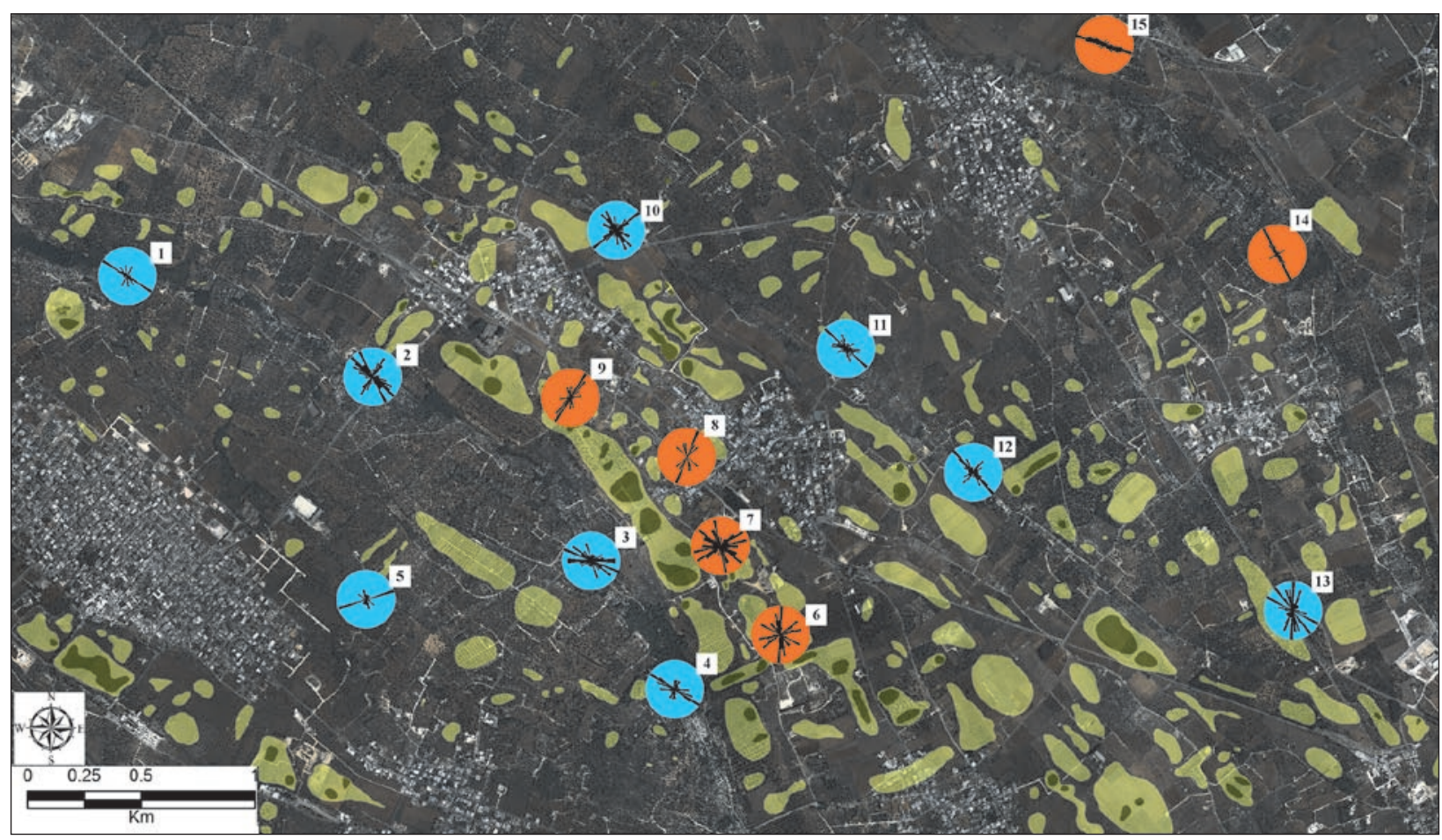

Fig. 12: Results of the structural measurements on the Cretaceous limestones (blue rose diagrams) and on the Miocene-Pleistocene calcarenites (orange rose diagrams). The forms in light and dark green are, respectively, depressions and dolines, as represented in the hydro-geomorphological map in fig. 4.

values appear to be more scattered, even though the peaks are still within the main Apenninic trend (Fig. 11, Tab. 2).

\section{TECTONIC AND/OR STRATIGRAPHIC CONTROL IN DEVELOPMENT OF KARST}

The structural setting of the study area, and more in general that of the whole Salento Peninsula, is characterized by gentle bending and high-angle, mainly normal faults, strongly affecting the regional-scale morphology.

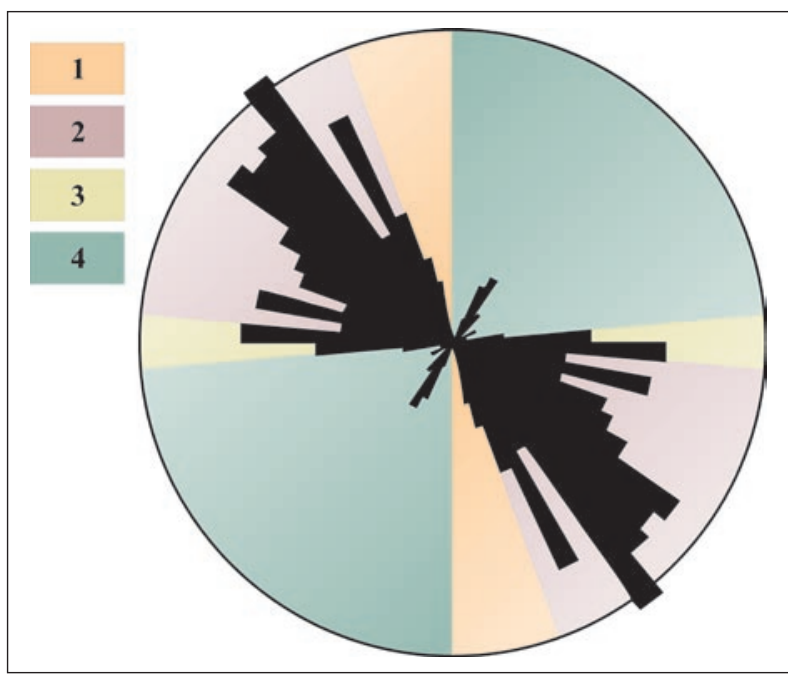

The most important fault systems are represented by normal, NW-SE and NNW-SSE-trending faults (Apenninic faults), affecting the Cretaceous and EoceneMiocene units. These fault systems, showing evidences of strike-slip movement (Tozzi 1993; Gambini \& Tozzi 1996), dissect the wide Salento horst into uplifted and lowered blocks, resulting in alternating morpho-structural ridges (the Serre Salentine ridges) and elongated depressions. Apenninic faults are also responsible for

Fig. 13: Trends of regional faults in the Southern Murge and the Salento Peninsula (after Tozzi 1993). Legend: 1. NNW-SSE trending faults (sub-vertical, strike-slip and dip-slip normal faults, best represented by the morpho-tectonic scarps bordering the Serre highlands in the Salento area), connected with the post-orogenic extension in the Apulian foreland (Miocene-post Pliocene); 2. NW-SE trending faults (dip-slip normal and subvertical faults, best developed in the Murge highland, producing a horst-and-graben setting), connected with the post-orogenic extension in the Apulian foreland (Miocene); 3. E-W trending faults (sub-vertical, dip-slip normal faults), characterizing the boundary between the Murge highland and the Salento area (Eocene-Oligocene); 4. NE-SW trending faults (sub-vertical, dip-slip normal faults; Plio- Pleistocene). 
the main slopes bordering both the Adriatic and the Ionian sides of the peninsula (e.g. Neboit 1975; Baldassarre et al. 1978; Delle Rose \& Parise 2003); some authors, instead, interpreted the Adriatic slopes as the original edge of the Mesozoic carbonate platform (Bosellini et al. 1999). Both NW-SE and NNW-SSE-trending fault systems first activated in Eocene-Oligocene, together with open to gentle folds (Festa et al. 2012), at the onset of Apennines orogenesis. However, Apenninic faults show evidences of reactivation in Pliocene and Pleistocene times (e.g. Tozzi 1993; Pieri et al. 1997; Delle Rose 2001; Festa et al. 2012), possibly related to the post-orogenic extension in the Apulian foreland (Tozzi 1993). A secondary fault system is represented by normal, NE-SWtrending faults (anti-Apenninic faults), which become preponderant just in local reliefs of the peninsula, such as near Otranto town (Tozzi 1993). Recent meso-structural analyses by Di Bucci et al. (2009) ascribe both Apenninic and Anti-Apenninic faults to middle and late Pleistocene extensional tectonics. Finally, normal, EWtrending faults mark the boundary between the Murge and the Salento highlands, producing a series of slopes, best represented by the Soglia Messapica line, and progressively loosing significance far from this belt.
Structural data obtained by field measurements in the 15 selected stations (Fig. 12) indicate some slight differences depending on lithologies (Fig. 12). In the Cretaceous limestones exposed along the Serre Salentine ridges, joints often perform preferential orientations. In particular, in six measurement stations out of nine (stations 1, 2, 3, 4, 11 and 12 in Fig. 12) a net preponderance of Apenninic faults, striking N100 to N160 has been observed. In two stations (stations 5 and 10 in Fig. 12) Anti-Apenninic faults prevail, while no preferential orientation characterizes the joints at station 13 (Fig. 12). In the Miocene to Pleistocene calcarenites, instead, strong lateral changes are observed, with joints orientations following either Apenninic (stations 14 and 15 in Fig. 12) or anti-Apenninic (stations 8 and 9 in Fig. 12) trends, or none of them (stations 6 and 7 in Fig. 12).

The collected structural data show a good agreement between the local joint distribution and the regional tectonic lineations (Fig. 13). The comparison between the cumulative curves of the major axes for the analyzed karst features shows that the maximum peak for both depressions and dolines is for the Apenninic elongation. Furthermore, relative peaks observed in cumulative curves of dolines and of depressions perform a good fit.

\section{DISCUSSION AND CONCLUSION}

Identification and mapping of karst landforms in the Barbarano del Capo area allowed to sketch the main morphokarst features of this sector of Salento Peninsula, and to connect them to the general geological- structural setting. The morphometric analysis carried out separately on dolines and depressions highlights that density values, total areas and mean major axis / minor axis ratio and elongation are higher for depressions.

Furthermore, the evident preponderance of Apennines orientation of major axes, irrespective of age and mechanical properties of lithologies involved, suggests a primary control of post-orogenic structures on karst development. This represents an important outcome, which highlights the possibility that some of the karst landforms observed in the more recent deposits might be the surficial effect of relict and/or buried similar landforms in the underlying carbonate bedrock. In terms of consequences for the evaluation of geological hazards in karst (i.e., opening of sinkholes; Parise, 2010b) this has to be taken into the due account.

The structural analysis carried out on local joints, and the comparison with regional lineaments, allowed to present some considerations on the geological-tectonic control on karst landforms: despite the fact that major axes of karst depressions generally follow the main structures, some differences can be pointed out between the main parameters of dolines and depressions, which are mostly a function of the affected lithologies.

The main tectonic lineaments of the Salento peninsula have been the object of several specific studies (Bossio et al. 1987; Ciaranfi et al. 1988; Tozzi 1993), but still little is known about their control over development of karst landforms (Gil et al. 2013). The interest of this topic, which has also significant hydrogeological implications, should require additional data, covering the whole Salento Peninsula. The integration of the geomorphological karst data with those deriving from direct surveys and analysis in caves (Iurilli et al. 2009) should be in particular appropriate, in order to achieve a deeper knowledge of the water circulation pattern. 


\section{REFERENCES}

Andriani, G.F. \& N. Walsh, 2009: An example of the effects of anthropogenic changes on natural environments in the Apulian karst (southern Italy).- Environmental Geology, 58, 313-325.

Baldassarre, G., Boenzi, F., Ciaranfi, N., D’Alessandro, A., Dazzaro L., Iannone, A., Laviano, A., Loiacono, F., Maggiore, M., Pennetta, L., Pieri P., Rapisardi, L., Ricchetti, G., Sardella, A. \& N. Walsh, 1978: Dati preliminari sulla neotettonica dei fogli 148 (Vasto), 154 (Larino), 188 (Gravina di Puglia), 201 (Matera), 202 (Taranto) e 203 (Brindisi).- Pubbl. N. 155 del C.N.R., Progetto Finalizzato Geodinamica, 35-67.

Basso, A., Bruno, E., Parise, M. \& M. Pepe, 2013: Morphometric analysis of sinkholes in a karst coastal area of southern Apulia (Italy).- Environmental Earth Sciences, 70, 6, 2545-2559.

Beccarisi, L., Cacciatore, G., Chiriacò, L., Delle Rose, M., Giuri, F., Marras, V., Quarta, G., Resta, F. \& P. Solombrino, 2003: Le Vore di Barbarano: note descrittive e speleogenesi.- Thalassia Salentina, 26, $145-154$.

Boccaletti, M., Ciaranfi, N., Cosentino, D., Deiana, G., Gelati, R., Lentini, F., Massari, F., Moratti, G., Pescatore, T., Ricci Lucchi, F. \& L. Tortorici 1990: Palinspastic restoration and paleogeographic reconstruction of the peri-Tyrrhenian area during the Neogene.- Palaeogeogr., Palaeoclimat., Palaeoecol., 77, 41-50.

Bosellini, A., Bosellini, F.R., Colalongo, L., Parente, M., Russo, A. \& A. Vescogni, 1999: Stratigraphic architecture of the Salento coast from Capo D'Otranto to S. Maria di Leuca (Apulia, Southern Italy). Rivista Italiana di Paleontologia e Stratigrafia, 105, 3, 397-416.

Bossio, A., Mazzei, R., Monteforti, B. \& G. Salvatorini, 1987: Studi sul Neogene e Quaternario della Penisola Salentina: II. Evoluzione paleogeografica dell'area di Leuca nel contesto della dinamica mediterranea.- Quad. Ric. Centro Studi Geol. Ing., Lecce, $11,31-47$.

Bossio, A., Esu, D., Foresi, L.M., Girotti, O., Iannone, A., Luperto, E., Margiotta, S., Mazzei, R., Monteforti, B., Ricchetti, G. \& G. Salvatorini, 1998: Formazione di Galatone, nuovo nome per un'unità litostratigrafia del Salento (Puglia, Italia meridionale).- Atti Soc. Toscana Sc. Nat., 105, 151-156.

Bruno, E., Calcaterra, D. \& M. Parise, 2008a: Development and morphometry of sinkholes in coastal plains of Apulia, southern Italy. Preliminary sinkhole susceptibility assessment.- Engineering Geology, 99, 198-209.
Bruno, E., Calcaterra, D. \& M. Parise, 2008b: Author's reply to discussion by I. Yilmaz on "Development and morphometry of sinkholes in coastal plains of Apulia, southern Italy. Preliminary sinkhole susceptibility assessment".- Engineering Geology, 101, 285-287.

Casero, P., Roure, F., Endignoux, L., Moretti, I., Müller C., Sage, L. \& R. Vially, 1988: Neogene geodynamic evolution of the southern Apennines.- Mem. Soc. Geol. Ital., 41, 109-120.

Ciaranfi, N., Pieri, P. \& G. Ricchetti, 1988: Note alla Carta geologica delle Murge e del Salento (Puglia centro-meridionale).- Mem. Soc. Geol. Ital., 41, I, 449-460.

Calò, F. \& M. Parise, 2006: Evaluating the human disturbance to karst environments in southern Italy.Acta Carsologica, 35, 2, 47-56.

Cotecchia, V. \& M. Scuro, 2010: Portrait of a coastal karst aquifer: the city of Bari.- AQUA Mundi, 187-196.

Cucchi, F., Marinetti, E., Potleca, M. \& L. Zini, 2001: Influence of geostructural conditions on the speleogenesis of the Trieste Karst (Italy).- Geologica Belgica, 4, 3-4, 241-250.

De Giorgi, C., 1896: Le vore di Barbarano.- L'Universo, 9, 129-131.

Delle Rose, M., 2001: Salento Miocene: a preliminary palaeoenvironmental reconstruction.- Thalassia Salentina, 25, 159-197.

Delle Rose, M. \& M. Parise, 2002: Karst subsidence in south-central Apulia Italy.- International Journal of Speleology, 31 (1/4), 181-199.

Delle Rose, M. \& M. Parise, 2003: Il condizionamento di fattori geologico-strutturali e idrogeologici nella speleogenesi di grotte costiere del Salento.- In: Proc. XIX Nat. Congr. Spel., Bologna, 27-31 August 2003, 27-36.

Delle Rose, M. \& M. Parise, 2005: Speleogenesi e geomorfologia del sistema carsico delle Grotte della Poesia nell'ambito dell'evoluzione quaternaria della costa Adriatica Salentina.- Atti e Memorie Commissione Grotte "E. Boegan”, 40, 153-173.

Delle Rose, M., Federico, A. \& M. Parise, 2004: Sinkhole genesis and evolution in Apulia, and their interrelations with the anthropogenic environment.Natural Hazards and Earth System Sciences, 4, $747-755$ 
Delle Rose, M., Parise, M. \& G.F. Andriani: 2007: Evaluating the impact of quarrying on karst aquifers of Salento (southern Italy).- In: Parise, M. \& J. Gunn (Eds.): Natural and anthropogenic hazards in karst areas: Recognition, Analysis and Mitigation. Geological Society, London, Special Publications 279, pp. 153-171.

Del Prete, S., Iovine, G., Parise, M. \& A. Santo, 2010: Origin and distribution of different types of sinkholes in the plain areas of Southern Italy.- Geodinamica Acta, 23, 1/3, 113-127.

De Pascalis, A., De Pascalis, F. \& M. Parise, 2010: Genesi ed evoluzione di un sinkhole connesso a cavità antropiche sotterranee nel distretto estrattivo di Cutrofiano (prov. Lecce, Puglia).- Proc. $2^{\circ}$ Workshop Int. "I sinkholes. Gli sprofondamenti catastrofici nell'ambiente naturale ed in quello antropizzato", Roma, 3-4 dicembre 2009, 703-718.

De Waele, J., Gutierrez, F., Parise, M. \& L. Plan, 2011: Geomorphology and natural hazards in karst areas: a review.- Geomorphology, 134, 1-2, 1-8.

Di Bucci, D., Coccia, S., Fracassi, U., Iurilli, V., Mastronuzzi, G., Palmentola, G., Sansò, P., Selleri, G. \& G. Valensise, 2009: Late Quaternary deformation of the southern Adriatic foreland (southern Apulia) from mesostructural data: preliminary results.Italian Journal of Geosciences, 128, 1, 33-46.

Doglioni, C., 1991: A proposal of kinematic modelling for W-dipping subductions - Possibile applications to the Tyrrenian-Apennines system.- Terra Nova, 3 , 423-434.

Drake, J.J. \& Ford, D.C., 1972: The analysis of growth patterns of two-generation populations: the example of karst sinkholes.- Can. Geogr., 16, 381-384.

Dunne, T., 1990: Hydrology, mechanics, and geomorphic implications of erosion by subsurface flow. In: Higgins, C.G. \& D.R. Coates, (Eds.): Groundwater geomorphology. Geological Society of America spec. paper 252, pp. 1-28.

Festa, V., Fiore, A., Parise, M. \& A. Siniscalchi A., 2012: Sinkhole evolution in the Apulian karst of southern Italy: a case study, with some considerations on sinkhole hazards.- Journal of Cave and Karst Studies, 74, 2, 137-147.

Funiciello, R., Montone, P., Parotto, M., Salvini, F. \& M. Tozzi, 1991: Geodynamic evolution of an intraorogenic foreland: the Apulia case history (Italy).Boll. Soc. Geol. It., 110, 419-425.

Gambini, R. \& M. Tozzi, 1996: Tertiary geodynamic evolution of the Southern Adria microplate.- Terra Nova, $8,593-602$.
Gil, H., Pepe, M., Soriano, M.A., Parise, M., Pocoví, A., Luzón, A., Pérez, A. \& A. Basso, 2013: Sviluppo ed evoluzione di sprofondamenti in rocce solubili: un confronto tra il carso coperto del Bacino dell'Ebro (Spagna) e la Penisola Salentina (Italia).- Memorie Descrittive Carta Geologica d'Italia, 93, 253-276.

Giuliani, P., 2000: Elenco delle grotte pugliesi catastate al 31 ottobre 1999.- Itinerari Speleologici, 9, 5-41.

Iurilli, V., Cacciapaglia, G., Selleri, G., Palmentola, G. \& G. Mastronuzzi, 2009: Karst morphogenesis and tectonics in south-eastern Murge (Apulia, Italy).Geogr. Fis. Dinam. Quat., 32, 145-155.

Lollino, P. \& M. Parise, 2010: Analisi numerica di processi di instabilità di cavità sotterranee e degli effetti indotti in superficie.- Proc. $2^{\text {nd }}$ Int. Workshop "I sinkholes. Gli sprofondamenti catastrofici nellambiente naturale ed in quello antropizzato", Rome, 3-4 december 2009, 803-816.

Lollino, P., Martimucci, V. \& M. Parise, 2013: Geological survey and numerical modeling of the potential failure mechanisms of underground caves. Geosystem Engineering, 16, 1, 100-112.

Lopez, N., Spizzico, V. \& M. Parise, 2009: Geomorphological, pedological, and hydrological characteristics of karst lakes at Conversano (Apulia, southern Italy) as a basis for environmental protection.- Environmental Geology, 58, 2, 327-337.

Margiotta, S., Negri, S., Parise, M. \& R. Valloni, 2012: Mapping the susceptibility to sinkholes in coastal areas, based on stratigraphy, geomorphology and geophysics.- Natural Hazards, 62, 2, 657-676.

Mills, H.H. \& D.D. Starnes, 1983: Sinkhole morphometry in a fluviokarst region: eastern Highland Rim, Tennessee, U.S.A.- Z. Geomorphol., 27, 39-54.

Mostardini, F. \& S. Merlini, 1986: Appennino Centro Meridionale e Proposta di Modello Strutturale.Mem. Soc. Geol. Ital., 35, 177-202.

Neboit, R., 1975: Plateaux et collines de Lucanie orientale et des Pouilles. Étude morphologique. Libr. Honore Champion, 715 pp, Paris.

Palmentola, G., 1987: Lineamenti geologici e morfologici del Salento leccese.- Quaderni Ricerche Centro Studi Geotecnica e di Ingegneria, 11, 7-30, Lecce.

Parise, M., 2003: Flood history in the karst environment of Castellana-Grotte (Apulia, southern Italy).- Natural Hazards and Earth System Sciences, 3, 6, 593-604.

Parise, M., 2006: Geomorphology of the Canale di Pirro karst polje (Apulia, Southern Italy).- Zeitschrift für Geomorphologie N.F. 147, 143-158. 
Parise, M., 2008a: I sinkholes in Puglia.- In: Nisio S. (Ed.) I fenomeni naturali di sinkhole nelle aree di pianura italiane.- Memorie Descrittive della Carta Geologica d'Italia, 85, 309-334.

Parise, M., 2008b: Elementi di geomorfologia carsica della Puglia.- In: Parise M., Inguscio S. \& Marangella A. (eds.), Atti del $45^{\circ}$ Corso CNSS-SSI di III livello di "Geomorfologia Carsica. Grottaglie, 2-3 febbraio 2008, 93-118.

Parise, M., 2009: Lakes in the Apulian karst (Southern Italy): geology, karst morphology, and their role in the local history.- In: Miranda, F.R. \& L.M. Bernard, (eds.) Lake pollution research progress. Nova Science Publishers, Inc., New York, pp. 63-80.

Parise, M., 2010a: The impacts of quarrying in the Apulian karst.- In: Carrasco F., La Moreaux J.W., Duran Valsero J.J. \& Andreo B. (eds.), Advances in research in karst media. Springer, 441-447.

Parise, M., 2010b: Hazards in karst.- In: O. Bonacci (Ed.) "Sustainability of the karst environment. Dinaric karst and other karst regions". IHP-UNESCO, Series on Groundwater no. 2, 155-162.

Parise, M. \& J. Gunn (eds.), 2007: Natural and anthropogenic hazards in karst areas: Recognition, Analysis and Mitigation.- Geological Society, London, Special Publications, 279.

Parise, M. \& P. Lollino, 2011: A preliminary analysis of failure mechanisms in karst and man-made underground caves in Southern Italy.- Geomorphology, 134, 1-2, 132-143.

Parise, M., Federico, A., Delle Rose, M. \& M. Sammarco, 2003: Karst terminology in Apulia (southern Italy).- Acta Carsologica, 32, 2, 65-82.

Pepe, M. \& M. Parise, 2011: Structural control in sinkhole development: the case study of Barbarano del Capo (Salento peninsula, Apulia region, South-East Italy).- Proc. $1^{\text {st }}$ Int. Workshop "Methods and Technologies for Environmental Monitoring and Modelling: Landslides and Ground Water Dynamics", Potenza, 29 September - 3 October 2011, 153-157.

Pieri, P., Festa, V., Moretti, M. \& M. Tropeano, 1997: Quaternary tectonic of the Murge area (Apulian foreland - Southern Italy).- Annali di Geofisica, 40, $5,1395-1404$.
Ricchetti, G., 1980: Contributo alla conoscenza strutturale della Fossa Bradanica e delle Murge.- Boll. Soc. Geol. It., 49, 4, 421-430.

Ricchetti, G. \& N. Ciaranfi, 2009: Note illustrative della Carta Geologica d'Italia alla scala 1:50.000, foglio 536 “Ugento", 121 pp., Litografia Artistica Cartografica S.r.l., Firenze(website http://www.isprambiente. gov.it/Media/carg/note_illustrative/536_Ugento. pdf).

Ricchetti, G., Ciaranfi, N., Luperto Sinni, E., Mongelli, F. \& P. Pieri, 1988: Geodynamics and sedimentary and tectonic evolution of the Apulian Foreland [in italian].- Mem. Soc. Geol. It., 41, 57-82.

Royden, L., Patacca, E. \& P. Scandone, 1987: Segmentation and configuration of subducted lithosphere in Italy: an important control on thrust-belt and foredeep-basin evolution.- Geology, 15, 714-717.

Sammarco, M. \& M. Parise, 2008: Cavità artificiali per uno studio di storia salentina: il caso dell'ipogeo di Leuca Piccola a Barbarano (Lecce).- Proc. XX Congr. Naz. Speleologia, Iglesias, Memorie dell'Istituto Italiano di Speleologia, s. II, 21, 546-550

Schumm, S., 1956: Evolution of drainage systems and slopes in badland at Perth Amboy, New Jersey.- Bulletin of Geological Society of America, 67, 597-646.

Šebela, S., 1998: Tectonic structure of Postojnska Jama cave system.- Založba ZRC 18, 112 pp., Ljubljana.

Šebela, S., Gosar, A., Košták, B. \& J. Stemberk, 2005: Active tectonic structures in the W part of Slovenia Setting of micro-deformation monitoring net.- Acta Geodyn. Geomater., 2, 1, 45-57, Prague.

Tozzi, M., 1993: Assetto tettonico dell'Avampaese Apulo meridionale (Murge meridionali-Salento) sulla base dei dati strutturali.- Geologica Romana, 29, 95-111.

Waltham, T., Bell, F. \& M. Culshaw, 2005: Sinkholes and Subsidence: Karst and Cavernous Rocks in Engineering and Construction.- Springer Praxis, Berlin.

Williams, P.W., 1971: Illustrating morphometric analysis of karst with examples from New Guinea.- Z. Geomorphol., 15, 40-61. 